\title{
Determination of the High School Students' Attitudes towards Their Teachers
}

\section{Yücel Gelişli}

Prof., corresponding author, Gazi University, Education Faculty, Department of Educational Sciences, Ankara, Turkey,ygelisli@gmail.com

\section{Dossym Kh. Baidrahmanov}

Prof., L.N. Gumilyov Eurasian National University, Faculty of Philology, Astana, Kazakhstan, baidrakhmanov_dkh@enu.kz

\section{Lyazzat Beisenbaeva}

PhD candidate. L.N. Gumilyov Eurasian National University, Faculty of Philology, Astana, Kazakhstan,aishalyaz@mail.ru

\section{Malik Sultanbek}

PhD., International Kazakh-Turkish University Named By H.A.Yasavi, Turkishtan, Kazakhstan,malik_sultanbek@mail.ru towards their teachers depending on some variables and the relationship between their attitudes and achievements. Thus, the study was designed according to relational survey model. The population of the study, which was specified based on the purposive sampling method, was comprised of 220 ninth and twelfth graders attending a state high school in the city of Ankara. In the current study, "The Scale of Students' Attitudes towards the Teacher (SOSATT)" was used as a data collection instrument to elicit the students' attitudes towards their teachers. The reliability co-efficient of the scale was 0.886 . A positive and moderately significant correlation was found between the ninth grade students' achievement scores and their attitude scores taken from the sub-dimensions of the scale and from the whole scale. Finally, teachers can be suggested to establish more effective communication with their students and to use methods and strategies that can enhance academic achievement.

Keywords: teacher, attitude, achievement, students' attitudes, high school students, determination 


\section{INTRODUCTION}

The main goal of an education system is to educate qualified people and in this regard, the main responsibility needs to be taken by the teacher. One of the smallest units contributing to the accomplishment of this goal is the class functioning within a certain system. Establishment of positive or negative atmosphere in the class depends on the teacher's classroom management skills to a great extent. That is, the only task of the teacher is not to convey information but also to establish a good classroom climate and to manage it effectively (Kılıç \& Aydın, 2016).

The first person interacted by beginning students at school is the teacher. Students get to know the school, classes and instructional settings through their interactions with their teachers. Students loving their teachers are more likely to enjoy their classes and to feel committed to their classes and school environment. For a successful instruction to occur, emotional and social relationships between students and the teacher as well as the teacher's knowledge and skills are of great importance.

Positive relations established between students and the teacher have great influence on the development of positive attitudes towards the teacher. Thus, teachers can exercise an enormous influence on the formation of attitudes and behaviors in the class and towards the teacher. A positive correlation was found between teachers' displaying democratic attitudes and behaviors towards their students and the development of students' different thinking skills. It has also been reported that teachers' democratic attitudes promote the development of students' risk-taking skills defined as students' seeking for new alternatives, ability of understanding complex problems or ideas, defending their own ideas, being courageous, making predictions, leveling self-criticism and clearly expressing failures. Students stated that the reason for some of their undesired behaviors in class is their dislike for the school or the class. Their main reason for not liking the school or the class is their not liking their teacher. The reasons stated by these students for not liking their teacher are their teacher's not listening to them, always allowing the same students to speak, making discrimination among students etc. (Erdoğdu, 2006; Ministry of National Education, 2014).

The teacher's personal and professional qualifications effect his/her attitudes and behaviors. The teacher's attitudes and behaviors related to classroom management affect the classroom climate including emotions, attitudes, values and relationships of students and the teacher and also exercise influence on the extent of learning, selfefficacy perception and accomplishment of the goals of the education program (Good \& Brophy, 1997; Varış, 1998; Sezgin, 2013). For instruction to be effective, the teacher and students need to attend the class willingly. In the establishment of such an environment, the biggest responsibility should be taken by the teacher. A teacher must be loving, considerate and funny. Loving teachers establish positive relationships with their students. They address their students with their names, are interested in their students' personal problems, are aware that each student is a different individual and make students feel this. Such teachers can gain the trust of their students. Thus, students are more likely to like their teachers and classes (Erden, 2000). 
Teachers have strong impacts on students' learning and on the elements of learning such as interest, motivation and attitude (Karakuş, 2009:140). Rewards and reinforcements used by teachers play an important role in all the stages of learning process, students' gaining information, skills and attitudes and making these acquired behaviors permanent. The response given by the teacher to a behavior displayed by a student and the effect of this response on the student are of great importance. If the teacher's response makes the student relaxed; then, the student's relevant behavior is expected to be repeated (Arslan, 2007).

A student feels much more comfortable in the class of a teacher to whom he/she feels close, who values the student as a person and treats him/her in a friendly manner than in the class of a teacher who does not show concern for the student. In classes where trust and respect-based warm relationships are established between the teacher and students, productivity increases, discipline problems decrease and likelihood of achieving educational goals increases (Açıkgöz, 1996).

Among the student qualities determining the learning level are affective input characteristics are of special importance. Though it might seem that cognitive behaviorsbased education-instructional settings are effective, affective behaviors determine the direction to be taken by students in these settings. Some of the prominent affective behaviors are love, hatred, fear, sadness and attitude. What students are ready to learn in terms of affective dimension depends on their interests and attitudes (Bloom, 2012; Semerci \& Semerci, 2004: 139).

Attitude can be defined as positive or negative behaviors developed by a person in relation to an object, a concept or a state. Attitudes are not in-born but they are learned behaviors. Attitudes are gained through direct experience with the object, reinforcement, imitation and social learning. Many of the attitudes are acquired from other people. For instance, families, teachers, friends and other living things affect the formation of attitudes (Kağıtçıbaşı, 2013; Çetin, 2006: 30).

On the basis of various theoretical approaches, different definitions of attitude have been proposed. According to Şerif \& Şerif (1996), attitude refers to a constant state of readiness determining the affective reaction; either positive or negative, to be given by an individual to an object or a state marked with any value judgment of a psychological process. Freedman, Sears and Carlsmith (2003) define attitude as a permanent system involving a behavioral tendency together with cognitive and affective elements. As cited by Cüceloğlu (2005), according to Baron and Byrne (1977), attitudes are long-term affective, belief-induced and behavioral tendencies. Two common features of these definitions are attitudes' being long-term or permanent and comprised of cognitive, affective and behavioral elements (Zan \& Di Martino, 2007).

Attitude is an important factor for success. When considered from this perspective, educational process is expected to contribute to the development of positive attitudes. In the formation of attitudes, the school and the classroom environment are of great importance. Attitudes developed by students towards their teachers, classes, schools etc. affect their education life and future because each student is in class with his/her 
emotions and with them, they participate in lessons, conduct activities and interact with their teachers and friends. In the formation of attitudes in an educational setting, the most important role should be fulfilled by the teacher. Teachers can also play important roles in the formation of students' attitudes towards their teachers and schools, their attending the school and school achievement. Particularly in the puberty period in which communication gains a special importance, students' relationships with their teachers affect their attitudes towards classes to a greater extent (Bloom, 2012; Semerci \& Semerci, 2004; MONE: 2014).

In research focusing on attitudes, it has been revealed that there is a significant relationship between students' school achievement and attitudes. Erdoğdu (2007) conducted a study entitled "Relationships between parents' attitudes, teachers' behaviors and students' academic achievement" and found that teachers' attitudes have a significant effect on students' achievement. In this regard, it can be argued that there is a significant relationship between teachers' behaviors and students' academic achievement. Satisfaction from the student-teacher interaction and the teacher's exhibiting tolerant and democratic attitudes were found to have important influence on the student's achievement.

Chidolue (1996) reported a correlation between effective teacher qualifications and students' attitudes, learning and achievement. It has also been reported in the literature that students loving their teachers invest more efforts for their classes and become more successful. For students, being accepted and loved by their teachers is a very important psychological need. Being criticized and not being liked make students scared and unsuccessful. Teachers' authoritarian attitudes, lack of information, indifference to their profession and students, giving their instruction without caring about knowing their students, unpreparedness for their classes are other reasons behind students' failure (Taş, 2005; MONE, 2014).

According to Ergin (2006), a student's displaying positive attitude towards a class results in an increase in his/her success in this class. Factors such as the learning climate to be established in the class by the teacher, students' active participation in the class, methods adopted by students to study, their expectations from the class and working environment affect students' attitudes towards this class (Aktepe and at all, 2014: 263). From the above-mentioned research, it seems to be clear that students' attitudes towards their teachers affect their academic achievement. However, there have been no studies concerning students' attitudes towards the teacher and its' relationship between students' academic achievement. In this connection, the current study aimed at determining students' attitudes towards their teachers and their effects on their academic achievement.

\section{Purpose}

The purpose of the current study is to determine the high school students' attitudes towards their teachers depending on some variables and the relationship between their attitudes and achievements. To this end, answers to the following questions were sought: 
1. Do the students' attitudes towards their teachers vary significantly depending on grade level variable?

2. Do the students' attitudes towards their teachers vary significantly depending on gender variable?

3. Is there a significant correlation between the ninth grade students' achievement and attitudes towards their teachers?

4. Depending on their gender, is there a significant correlation between the ninth grade students' achievement and attitudes towards their teachers?

\section{METHOD}

\section{Research Design}

The current study conducted according to general survey model employed the descriptive method. In the current study, it was intended to describe whether there is a significant difference in students' attitudes towards their teachers due to some variables and the relationship between students' attitudes towards their teachers and academic achievement. Therefore, the current study was designed in the form of relational survey model.

The relational survey model is generally used to determine the existence and degree of the relationship between two or more variables. These relationships can be determined through statistical techniques such as correlation, t-test, variance analysis and multiple regression (Metin, 2014; Büyüköztürk, 2013; Özdamar, 2013).

\section{Research Population}

The population of the study was determined based on the purposive sampling method. It was comprised of 220 ninth and twelfth grade students attending a state school in the city of Ankara. The application was conducted within the biology course and biology course grades were taken as the academic achievement of the students.

\section{Data Collection Instrument}

In the study, in order to determine the students' attitudes towards their teachers, "The Scale of Students' Attitudes towards the Teacher (SOSATT)" developed by Gelişli and Beisenbayeva (2016) and whose validity and reliability studies were conducted was used as a data collection instrument. The scale is in the form of five-point Likert-type including 25 items. SOSATT has four sub-dimensions. These are:

$\checkmark$ Teachers' Personality Characteristics (TPC): This sub-dimension is related to students' opinions about their teachers' positive personality characteristics and attitudes towards these characteristics. In this sub-dimension, items $1,5,6,10,13$, $16,18,21,22,24$ and 25 are included. The possible highest score to be taken from this dimension is 55 .

$\checkmark$ Attitudes towards Classroom Management (ATCM): This sub-dimension is related to some classroom management qualities of teachers and students' attitudes towards these qualities. Items 2, 8,19 and 23 are in this dimension. The highest score to be taken from this dimension is 20 . 
$\checkmark$ Interaction with the Teacher (IWT): This sub-dimension is related to studentteacher interaction, students' communication with their teachers and whether students are willing to communicate with their teachers. This dimension includes the items $3,11,15,17$ and 20 . The possible highest score to be taken from this dimension is 25 .

$\checkmark \quad$ Negative Attitude towards the Teacher (NATT): This sub-dimension is related to students' negative opinions about and attitudes towards their teachers. This dimension includes the items 4, 7, 9, 12 and 14 . The possible highest score to be taken from this dimension is 25 .

As the items 4, 7, 9, 12, 14 and 15 in the scale are negative items, they are reversely coded. The Cronbach Alpha reliability coefficients of the sub-dimensions of the scale are as follows: for the first sub-dimension it is 0.876 ; for the second sub-dimension it is 0.718 ; for the third sub-dimension it is 0.710 ; for the fourth sub-dimension it is 0.702 . Reliability value for the whole scale is 0.886 (If $0.80 \leq \alpha<1.00$, then the scale is highly reliable). This shows that the scale is highly reliable (Turgut, 1992).

\section{Data Analysis}

The study aimed to investigate the students' attitudes towards their teachers depending on some variables (gender, grade level) and to investigate the relationship between their attitudes and academic achievement.

By using Kolmogorov-Smirnov Normal Distribution Test, it was tested whether the data related to the sub-dimensions and general total scores exhibit normal distribution. The test revealed that scores of the four sub-dimensions and SOSATT general score do not show normal distributions $(\mathrm{p}<.05)$. Therefore, comparisons were conducted by using non-parametric Mann Whitney U Test and Kruskal Wallis Test and correlations were tested by using Spearman Brown Rank Correlation Coefficient (Büyüköztürk, 2013; Green \& Salkind, 2008; Kalayc1, 2005; Özdamar, 2013).

\section{FINDINGS}

In this section, findings obtained from the statistical analysis of the data collected about the students' attitudes towards their teachers are presented.

\section{Students' Attitudes towards Their Teachers}

Means and standard deviations of the students' responses to each item in the scale are given in Table 1. 
Table 1

Findings Obtained from the Whole Scale about the Students' Attitudes towards their Teachers

\begin{tabular}{|c|c|c|c|}
\hline Scale Items & $\mathrm{N}$ & $(\bar{X})$ & $(\mathrm{S})$ \\
\hline I think that teachers are role models & 220 & 3,85 & 1,12 \\
\hline I appreciate teachers who are honest to their students & 220 & 4,37 & 1,06 \\
\hline I like listening to teachers & 220 & 3,76 & 1,16 \\
\hline I think that teachers are not competent enough in their subject area & 220 & 3,91 & 1,26 \\
\hline I think that teachers approach to their students with love & 220 & 3,69 & 1,14 \\
\hline Teachers are honest people & 220 & 3,73 & 1,11 \\
\hline If I did not have to, I would not greet my teachers & 220 & 4,09 & 1,39 \\
\hline $\begin{array}{l}\text { I enjoy listening to teachers establishing effective communication with } \\
\text { students }\end{array}$ & 220 & 4,18 & 1,15 \\
\hline I think that teachers are very boring people & 220 & 3,89 & 1,34 \\
\hline I think that in each case teachers are supportive to their students & 220 & 3,47 & 1,28 \\
\hline I am happy to communicate with teachers & 220 & 3,99 & 1,18 \\
\hline I do not mind teachers & 220 & 4,17 & 1,25 \\
\hline I think that teachers teach their classes very well & 220 & 3,52 & 1,05 \\
\hline I always hate teachers & 220 & 4,29 & 1,27 \\
\hline I do not want to meet teachers outside the class & 220 & 3,78 & 1,39 \\
\hline I think that teachers are self-sacrificing & 220 & 3,30 & 1,19 \\
\hline When I see my teachers on the street, I want to greet them & 220 & 3,94 & 1,31 \\
\hline I think that teachers are ideal people & 220 & 3,59 & 1,15 \\
\hline I appreciate teachers having democratic attitudes & 220 & 3,97 & 1,21 \\
\hline I enjoy working together with teachers & 220 & 3,75 & 1,34 \\
\hline I think that teachers enjoy doing their job & 220 & 3,58 & 1,31 \\
\hline I believe that all teachers like their students & 220 & 3,39 & 1,35 \\
\hline I like teachers who enjoy doing their job & 220 & 4,32 & 1,04 \\
\hline I believe that teachers do their best for us & 220 & 3,86 & 1,15 \\
\hline I think that teachers have humanistic characteristics & 220 & 3,92 & 1,15 \\
\hline
\end{tabular}

When the scores given in Table 1 are examined, it is seen that the majority of the students' attitude scores are over the level of agreement. The lowest agreement is with the item "I think that in each case teachers are supportive to their students" $(X=3.47)$ and the highest agreement is with the item "I like teachers who enjoy doing their job" $(X=4.32)$. It can be argued that the students' attitudes towards their teachers are positive in general.

\section{Investigation of the Students' Attitudes towards their Teachers in terms of Some Variables}

The findings related to whether the students' attitudes towards their teachers vary significantly depending on some variables are discussed here. In this regard, it was investigated whether there is a significant difference between the ninth grade students' attitudes towards their teachers and those of the twelfth grade students. Yet, as SOSATT scores did not exhibit normal distribution, the comparison was made with Mann Whitney U Test.

The results of the statistical analysis of the students' grade level-based attitudes towards their teachers are given in Table 2. 
Table 2

Comparison of the SOSATT scores of the ninth and twelfth grade students (Mann Whitney U Test)

\begin{tabular}{|c|c|c|c|c|c|c|c|c|}
\hline \multicolumn{2}{|l|}{ Group } & $\mathrm{N}$ & $\bar{X}$ & S & $\begin{array}{l}\text { Mean } \\
\text { Rank }\end{array}$ & Rank Sum & U Value & $\mathrm{p}$ \\
\hline \multirow{2}{*}{$\begin{array}{l}\text { The teacher's } \\
\text { personality } \\
\text { characteristics } \\
\text { (TPC) }\end{array}$} & \multirow{2}{*}{$\begin{array}{l}9^{\text {th }} \\
\text { grade } \\
12^{\text {th }} \\
\text { grade }\end{array}$} & 109 & 41,32 & 8,59 & 119,95 & 13074,50 & \multirow[b]{2}{*}{5019,500} & \multirow[b]{2}{*}{0,029} \\
\hline & & 111 & 38,49 & 8,89 & 101,22 & 11235,50 & & \\
\hline \multirow{2}{*}{$\begin{array}{l}\text { Attitudes towards } \\
\text { Classroom } \\
\text { Management } \\
\text { (ATCM) }\end{array}$} & \multirow{2}{*}{$\begin{array}{l}9^{\text {th }} \\
\text { grade } \\
12^{\text {th }} \\
\text { grade }\end{array}$} & 109 & 16,08 & 3,82 & 96,80 & 10551,00 & \multirow[b]{2}{*}{4556,000} & \multirow[b]{2}{*}{0,001} \\
\hline & & 111 & 17,58 & 2,93 & 123,95 & 13759,00 & & \\
\hline \multirow{2}{*}{$\begin{array}{l}\text { Interaction with } \\
\text { the teacher (IWT) }\end{array}$} & \multirow{2}{*}{$\begin{array}{l}9^{\text {th }} \\
\text { grade } \\
12^{\text {th }} \\
\text { grade }\end{array}$} & 109 & 19,29 & 4,57 & 111,03 & 12102,00 & \multirow{2}{*}{5992,000} & \multirow{2}{*}{0,903} \\
\hline & & 111 & 19,15 & 4,74 & 109,98 & 12208,00 & & \\
\hline \multirow{2}{*}{$\begin{array}{l}\text { Negative attitudes } \\
\text { towards the } \\
\text { teacher (NATT) }\end{array}$} & \multirow{2}{*}{$\begin{array}{l}9^{\text {th }} \\
\text { grade } \\
12^{\text {th }} \\
\text { grade }\end{array}$} & 109 & 19,67 & 4,35 & 99,70 & 10865,50 & \multirow[b]{2}{*}{4872,500} & \multirow{2}{*}{0,012} \\
\hline & & 111 & 21,02 & 4,01 & 121,10 & 13442,50 & & \\
\hline \multirow{2}{*}{$\begin{array}{l}\text { Attitudes towards } \\
\text { the teacher } \\
\text { (SOSATT) }\end{array}$} & \multirow{2}{*}{$\begin{array}{l}9^{\text {th }} \\
\text { grade } \\
12^{\text {th }} \\
\text { grade }\end{array}$} & 109 & 96,35 & 17,97 & 111,17 & 12117,50 & \multirow{2}{*}{5976,500} & \multirow{2}{*}{0,877} \\
\hline & & 111 & 96,24 & 16,68 & 109,84 & 12192,50 & & \\
\hline
\end{tabular}

In Table 2, comparisons of the attitudes of the ninth grade students and twelfth grade students towards each sub-dimension of SOSATT are presented. When Table 2 is examined, it can be argued that depending on the grade level;

- A significant difference was found between the mean TPC scores of the groups (U=5019.500, $\mathbf{p}<.05)$. The ninth grade students' attitudes towards the teacher's personality characteristics are more positive than those of the twelfth graders.

- It was determined that there is a significant difference between the ATCM scores of the groups $(\mathbf{U}=\mathbf{4 5 5 6 . 0 0 0}, \mathbf{p}<\mathbf{. 0 5})$. The twelfth grade students' attitudes towards the teacher's classroom management are more positive than those of the ninth graders.

- There is no significant difference between IWT scores of the groups $(\mathrm{U}=5992.000, \mathrm{p}>.05)$.

- It was determined that there is a significant difference between the NATT scores of the groups $(\mathbf{U}=\mathbf{4 8 7 2 . 5 0 0}, \mathbf{p}<\mathbf{. 0 5})$. The twelfth graders' negative attitudes towards their teachers are more than those of the ninth graders.

- There is no significant difference between the SOSATT general mean scores of the groups ( $U=5976.500, \mathrm{p}>.05)$.

In light of the data presented in Table 2, it can be argued that the students' attitudes towards their teachers do not vary much throughout their high school education but ninth graders have more positive attitudes in relation to the first sub-dimension of the scale (TPC) and towards the twelfth grade, the students attitudes towards their teachers 
become more negative. In the second sub-dimension of the scale (ATCM), the twelfth grade students' attitudes are more positive. In the third sub-dimension of the scale (NATT), the twelfth grade students' attitudes are more negative. For the whole of the scale, no significant difference based on the grade level of the students between the students' attitudes was found.

It was also investigated whether the students' gender caused significant differences in the students' SOSATT scores. As SOSATT scores did not exhibit a normal distribution, comparison of the attitudes on the basis of gender variable was performed by using Mann Whitney U Test. The results of the statistical analysis of the students' attitudes depending on their gender are given in Table 3.

Table 3

Comparison of the students' SOSATT scores on the basis of their gender (Mann Whitney U Test)

\begin{tabular}{|c|c|c|c|c|c|c|c|c|}
\hline \multicolumn{2}{|l|}{ Group } & $\mathrm{N}$ & $\bar{X}$ & S & $\begin{array}{l}\text { Mean } \\
\text { Rank }\end{array}$ & Rank Sum & U Value & $\mathrm{p}$ \\
\hline The teacher's & Female & 100 & 39,83 & 9,03 & 110,31 & 11031,00 & \multirow[b]{2}{*}{5981,000} & \multirow[b]{2}{*}{0,968} \\
\hline $\begin{array}{l}\text { personality } \\
\text { characteristics } \\
\text { (TPC) }\end{array}$ & Male & 120 & 39,95 & 8,71 & 110,66 & 13279,00 & & \\
\hline \multirow{2}{*}{$\begin{array}{l}\text { Attitudes towards } \\
\text { Classroom } \\
\text { Management } \\
\text { (ATCM) }\end{array}$} & Female & 100 & 17,44 & 3,04 & 121,28 & 12128,00 & \multirow[b]{2}{*}{4922,000} & \multirow[b]{2}{*}{0,020} \\
\hline & Male & 120 & 16,33 & 3,74 & 101,52 & 12182,00 & & \\
\hline $\begin{array}{l}\text { Interaction with } \\
\text { the teacher (IWT) }\end{array}$ & $\begin{array}{l}\text { Female } \\
\text { Male }\end{array}$ & $\begin{array}{l}100 \\
120\end{array}$ & $\begin{array}{l}19,27 \\
19,17\end{array}$ & $\begin{array}{l}5,08 \\
4,27\end{array}$ & $\begin{array}{l}114,03 \\
107,56\end{array}$ & $\begin{array}{l}11402,50 \\
12907,50\end{array}$ & 5647,500 & 0,452 \\
\hline \multirow{2}{*}{$\begin{array}{l}\text { Negative attitudes } \\
\text { towards the } \\
\text { teacher (NATT) }\end{array}$} & Female & 100 & 21,12 & 4,02 & 123,26 & 12325,50 & \multirow[b]{2}{*}{4724,500} & \multirow[b]{2}{*}{0,006} \\
\hline & Male & 120 & 19,71 & 4,30 & 99,87 & 11984,50 & & \\
\hline \multirow{2}{*}{$\begin{array}{l}\text { Attitudes towards } \\
\text { the teacher } \\
\text { (SOSATT) }\end{array}$} & Female & 100 & 97,66 & 17,63 & 116,37 & 11637,00 & \multirow[b]{2}{*}{5413,000} & \multirow[b]{2}{*}{0,212} \\
\hline & Male & 120 & 95,16 & 16,99 & 105,61 & 12673,00 & & \\
\hline
\end{tabular}

In Table 3, comparisons of the attitudes of the male students and female students towards each sub-dimension of SOSATT are presented. When Table 3 is examined, it can be argued that depending on the gender;

- There is no significant difference between the TPC scores of the groups (U=5981.000, p>.05).

- There is a significant difference between the ATCM scores of the groups $(\mathbf{U}=\mathbf{4 9 2 2 . 0 0 0 ,} \mathbf{p}<.05)$. The female students' attitudes towards the teacher' classroom management are more positive than those of the male students.

- There is no significant difference between the IWT scores of the groups $(\mathrm{U}=5647.500, \mathrm{p}>.05)$.

- There is a significant difference between the NATT scores of the groups $(\mathbf{U}=\mathbf{4 7 2 4 . 5 0 0}, \mathbf{p}<.05)$. The female students' negative attitudes towards their teachers are more than those of the male students. 
- There is no significant difference between the SOSATT general scores of the groups $(\mathrm{U}=5413.000, \mathrm{p}>.05)$.

The data presented in Table 3 show that the students' attitudes towards their teachers do not vary significantly depending on the gender variable in terms of the general total scores from the scale. However, in the second sub-dimension of the scale (ATCM), the female students' attitudes towards the teacher's classroom management are more positive than those of the male students and in the third sub-dimension of the scale (NATT), the female students' attitudes are more negative.

The Relationship between the Ninth Grade Students' Attitudes towards their Teachers and Academic Achievement

It was investigated whether there is a significant difference between the ninth grade students' SOSATT scores and biology course academic achievement. As SOSATT score did not display a normal distribution, correlation analysis was conducted through Spearman Brown Rank Correlation Coefficient. The results of the analysis are given in Table 4.

Table 4

The correlation between the ninth grade students' biology course academic achievement and SOSATT scores (Spearman Brown Rank Correlation Coefficient)

\begin{tabular}{lccc}
\hline Variables & $\mathrm{N}$ & $\mathrm{r}$ & $\mathrm{p}$ \\
\hline Achievement *The teacher's personality characteristics (TPC) & 109 & 0,439 & 0,000 \\
\hline Achievement * Attitudes towards classroom management (ATCM) & 109 & 0,358 & 0,000 \\
\hline Achievement * Interaction with the teacher (IWT) & 109 & 0,499 & 0,000 \\
\hline Achievement * Negative attitudes towards the teacher (NATT) & 109 & 0,235 & 0,014 \\
\hline Achievment* Attitudes towards the teacher (SOSATT) & 109 & 0,462 & 0,000 \\
\hline
\end{tabular}

As a result of the calculation of Spearman Brown Rank Correlation Coefficient to see the correlation between the ninth grade students' biology course academic achievement and SOSATT scores;

- It was found that there is a medium level, positive and significant correlation between the academic achievement in biology course and TPC scores $(\mathbf{r}=\mathbf{0 . 4 3 9}$, $\mathbf{p}<.05$ ).

- It was found that there is a medium level, positive and significant correlation between the academic achievement and ATCM scores $(\mathbf{r}=\mathbf{0 . 3 5 8}, \mathbf{p}<.05)$.

- It was determined that there is a medium level, positive and significant correlation between the academic achievement and IWT scores $(\mathbf{r}=\mathbf{0 . 4 9 9}, \mathbf{p}<.05)$.

- It was found that there is a low level, positive and significant correlation between the academic achievement and NATT scores $(\mathbf{r}=\mathbf{0 . 2 3 5}, \mathbf{p}<.05)$.

- It was determined that there is a medium level, positive and significant correlation between the academic achievement and SOSATT general total scores $(\mathbf{r}=\mathbf{0 . 4 6 2}$, $\mathbf{p}<.05)$. 
On the basis of the data presented in Table 4, it was investigated whether there is a significant correlation between the students' academic achievement in biology course and SOSATT scores. As can be seen in the table, positive, low and medium level and significant correlations were found between the scores taken from the sub-dimensions of the scale and from the whole scale and the academic achievement in biology course. In the national and international literature, it has also been reported that there is a significant correlation between students' attitudes and their academic achievement and this general finding in the literature is supported with the finding of the current study (Ergin, 2006; Anders \& Berg, 2005; Erdoğdu, 2007; Chidolue, 1996; Y1lmazer \& Demir, 2014).

The relationship between the ninth grade students' academic achievement in biology course and their SOSATT scores depending on the gender variable

The effect of gender on the relationship between the ninth grade students' academic achievement in biology and their SOSATT scores was investigated. As the SOSATT scores did not exhibit a normal distribution, the correlation was calculated by using Spearman Brown Rank Correlation Coefficient. The results of the analysis are summarized in Table 5.

Table 5

The correlation between the ninth grade male and female students' academic achievement in biology course and SOSATT scores (Spearman Brown Rank Correlation Coefficient)

\begin{tabular}{llrrr}
\hline Gender & Variables & $\mathrm{N}$ & $\mathrm{r}$ & $\mathrm{p}$ \\
\hline \multirow{5}{*}{ Female } & Achievement * The teacher's personality characteristics (TPC) & 33 & 0,508 & 0,003 \\
\cline { 2 - 5 } & Achievement * Attitudes towards classroom management (ATCM) & 33 & 0,429 & 0,013 \\
\cline { 2 - 5 } & Achievement * Interaction with the teacher (IWT) & 33 & 0,530 & 0,002 \\
\cline { 2 - 5 } & Achievement * Negative attitudes towards the teacher (NATT) & 33 & 0,306 & 0,083 \\
\cline { 2 - 5 } Male & Achievement * Attitudes towards the teacher (SOSATT) & 33 & 0,534 & 0,001 \\
\hline \multirow{5}{*}{ Achievement * The teacher's personality characteristics (TPC) } & 76 & 0,402 & 0,000 \\
\cline { 2 - 5 } & Achievement* Attitudes towards classroom management (ATCM) & 76 & 0,329 & 0,004 \\
\cline { 2 - 5 } & Achievement * Interaction with the teacher (IWT) & 76 & 0,496 & 0,000 \\
\cline { 2 - 5 } & Achievement * Negative attitudes towards the teacher (NATT) & 76 & 0,218 & 0,059 \\
\cline { 2 - 5 } & Achievement* Attitudes towards the teacher (SOSATT) & 76 & 0,434 & 0,000 \\
\hline
\end{tabular}

As a result of the Spearman Brown Rank Correlation Coefficient calculation, for the female students, it was found that;

- There is a medium level, positive and significant correlation between academic achievement in biology course and TPC scores $(\mathbf{r}=\mathbf{0 . 5 0 8}, \mathbf{p}<.05)$.

- There is a medium level, positive and significant correlation between academic achievement and ATCM scores ( $\mathbf{r}=\mathbf{0 . 4 2 9}, \mathbf{p}<.05)$.

- There is a medium level, positive and significant correlation between academic achievement and IWT scores $(\mathbf{r}=\mathbf{0 . 5 3 0}, \mathbf{p}<.05)$.

- There is a medium level, positive and significant correlation between academic achievement and NATT scores ( $\mathrm{r}=0.306, \mathrm{p}>.05)$. 
- There is a medium level, positive and significant correlation between academic achievement and SOSATT general total scores $(\mathbf{r}=\mathbf{0 . 4 0 2}, \mathbf{p}<.05)$.

On the basis of the data presented in Table 5, it was investigated whether there is a significant correlation between the ninth grade female students' academic achievement scores in biology course and SOSATT scores. In light of the data presented in this table, it can be maintained that there are medium level, positive and significant correlations between the ninth grade female students' scores taken from the sub-dimensions of the scale and from the whole scale and the academic achievement scores in biology course.

For the male students, it was found that;

- There is a medium level, positive and significant correlation between academic achievement in biology course and TPC scores $(\mathbf{r}=\mathbf{0 . 4 0 2}, \mathbf{p}<.05)$.

- There is a medium level, positive and significant correlation between academic achievement and ATCM scores $(\mathbf{r}=\mathbf{0 . 3 2 9}, \mathbf{p}<.05)$.

- There is a medium level, positive and significant correlation between academic achievement and IWT scores $(\mathbf{r}=\mathbf{0 . 4 9 6}, \mathbf{p}<.05)$.

- There is a low level, positive and significant correlation between academic achievement and NATT scores $(r=0.218, \mathrm{p}>.05)$.

- There is a medium level, positive and significant correlation between academic achievement and SOSATT general total scores $(\mathbf{r}=\mathbf{0 . 4 3 4}, \mathbf{p}<.05)$.

On the basis of the data presented in Table 5, it was investigated whether there is a significant correlation between the ninth grade male students' academic achievement scores in biology course and SOSATT scores. The data presented in this table show that there are low and medium level, positive and significant correlations between the ninth grade male students' scores taken from the sub-dimensions of the scale and from the whole scale and the academic achievement scores in biology course.

In literature, there are similar findings of various studies on students' attitudes and academic achievement scores. Findings of this study is supported by the study of Gardner \& MacIntyre (1993), suggesting that there is a significant relationship between attitude and academic achievement. Additionally, Selçuk (1997) and Çoban (1989) argue that there is a positive relationship between attitude and academic achievement. Similarly, Kazazoğlu (2013) found out that the relationship between students' achievement scores and attitudes vary in different courses. In other words, in this study, it was found that although achievement scores of the students with positive attitude towards Turkish course was low, achievement scores of students who had positive attitude towards English course was high. To sum up, research findings show that there is a low or high positive relationship between students' academic achievement scores and attitudes towards the courses. 


\section{CONCLUSION AND SUGGESTIONS}

In the current study;

1. It was observed that the degree to which the high school students agree with the scale items is frequently or completely. Thus, it can be argued that the students' attitudes towards the teacher are positive in general.

2. It was found that the high school students' attitudes towards their teachers do not vary much throughout the high school years; but, in one sub-dimension of the scale (TPC), the ninth grade students have more positive attitudes and towards twelfth grade these attitudes become more negative. In the second sub-dimension of the scale (ATCM), on the other hand, the twelfth grade students' attitudes were found to be more positive. In the third sub-dimension of the scale (NATT), the twelfth grade students' attitudes were found to be more negative. For the whole scale, the students' attitudes towards their teachers were found to be not varying significantly depending on the grade level variable.

3. The gender of the ninth grade students was found to be not significantly affecting the students' attitudes towards the teacher in the total score of the scale. However, in the second sub-dimension of the scale (ATCM), the female students' attitudes towards the teacher's classroom management are more positive than those of the male students and in the third sub-dimension of the scale (NATT), the female students' attitudes are more negative. Low and medium level, positive and significant correlations between the ninth grade students' scores taken from the sub-dimensions of the scale and from the whole scale and the academic achievement scores in biology course were found.

5. Medium level, positive and significant correlations between the ninth grade female students' scores taken from the sub-dimensions of the scale and from the whole scale and the academic achievement scores in biology course were found.

6. Low and medium level, positive and significant correlations between the ninth grade male students' scores taken from the sub-dimensions of the scale and from the whole scale and the academic achievement scores in biology course were found.

In light of the findings of the current study, following suggestions can be made;

1. Though the students' attitudes towards their teachers were found to be positive in general, the correlation between the students' attitudes towards their teachers and academic achievement was found to be positive but low. Teachers can be suggested to establish more effective communication with their students and to use methods and strategies that can enhance academic achievement.

2. It was found that with students' increasing grade level, the students' attitudes towards their teachers' personality characteristics become more negative; thus, it can be suggested that teachers should exhibit more positive behaviors and democratic attitudes towards senior high school students. 


\section{REFERENCES}

Açıkgöz, K. Ü. (1996). Etkili ögrenme ve öğretme. İzmir: Kanyılmaz Matbaası.

Aktepe, V., Tahiroğlu, M., \& Sargın, S.(2014). İlkokul 4.sınıf öğrencilerinin sosyal bilgiler dersine yönelik tutumları, Türkiye Sosyal Araştırmalar Dergisi, 1, 259-272.

Anders, C., \& Berg, R. (2005). Factors related to observed attitude change toward learning chemistry among university students, Chemistry Education Research and Practice, 6(1), 1-18.

Arslan, H. (2007). İlköğretim okullarında istenmeyen davranışların düzeltilmesinde ödül ve cezanın ögrrenci davranışlarl üzerindeki etkisi. (Unpublished master thesis). Yeditepe Üniversitesi, İstanbul.

Bloom, S. B. (2012). Insan nitelikleri ve okulda öğrenme (D.A. Özçelik, Trans.). Ankara: Pegem.

Büyüköztürk, Ş. (2013). Sosyal bilimler için veri analizi el kitabı. Ankara: Pegem.

Chidolue M. E. (1996).The relationship between teacher characteristics, learning environment and student achievement and attitude. Studies in Educational Evaluation, 22(3), 263-274.

Cüceloğlu, D. (2005). Insan ve davranışı: Psikolojinin temel kavramları. İstanbul: Remzi.

Çoban, A. (1989). Ankara merkez ortaokullarındaki son sınıf öğrencilerinin matematik dersine ilişkin tutumları. (Unpublished master thesis). Gazi Üniversitesi, Ankara.

Çetin, Ş. (2006). Öğretmenlik mesleği tutum ölçeğinin geliştirilmesi (Geçerlik ve güvenirlik çalışması), G. Ü. Endüstriyel Sanatlar Eğitim Fakültesi Dergisi, 18, 28-37.

Erden, M. (2000). Sınıf yönetimi. İstanbul: Alkım.

Erdoğdu, M. (2006). Yaratıcılık ile öğretmen davranışları ve akademik başarı arasındaki ilişkiler. Elektronik Sosyal Bilimler Dergisi. (5), 95-106.

Erdoğdu, M. (2007). Ana baba tutumları ve öğretmen davranışları ile öğrencilerin akademik başarıları arasındaki ilişkiler. SAÜ Eğitim Fakültesi Dergisi. (14), 33-46.

Ergin, A. (2006). İlköğretim öğrencilerinin sosyal bilgiler dersine ilişkin tutumları. (Unpublished master thesis). Pamukkale Üniversitesi, Denizli.

Freedmann, J. L., Sears, D. O., \& Carlsmith, J. M. (2003). Sosyal psikoloji. (A. Dönmez, Çev.). Ankara: İmge.

Gardner, R. C., \& MacIntyre, P. D. (1993). A student's contribution to second language acquisition. Part II: Affective variables. Language Teaching, 26, 1-11. 
Gelişli, Y., \& Beisenbayeva, L. (2016, July). Öğretmene yönelik tutum ölçeğinin (ÖYTÖ) geçerlik ve güvenirliği. $2^{\text {nd }}$ International Confererence on Lifelong Education and Leadership for all. Liepaja University, Liepaja-Latvia.

Good, T. L., \& Brophy, J.E. (1997). Looking in classrooms. New York: Longman.

Green, S. B., \& Salkind, N. J. (2008). Using SPSS for windows and macintosh (Analyzing and Understanding Data-Fifth Edition). New Jersey: Pearson Prentice Hall.

Kağıtçıbaşı, Ç. (2013). Günümüzde insan ve insanlar. İstanbul: Evrim.

Kalayc1, Ş. (2005). SPSS uygulamalı çok değişkenli istatistik teknikleri. Ankara: Asil.

Karakuş, F. (2009). Sosyal bilgiler öğretiminde oluşturmacı öğrenme ve otantik değerlendirme yaklaşımlarının öğrencilerin sosyal bilgiler dersine yönelik tutumlarına ve kalıcılığa etkisi, Çukurova Üniversitesi Eğitim Fakültesi Dergisi, 3(36), 124-141.

Kazazoğlu, S. (2013). Türkçe ve ingilizce derslerine yönelik tutumun akademik başarıya etkisi, Ĕgitim ve Bilim, 38(170), 294-307.

Kılıç, D., \& Aydın, S. M. (2016). Sınıf öğretmenlerinin sınıf yönetimi eğilimleri. Ekev Akademi Dergisi, 65, 469-484.

Ministry of National Education (MONE).(2014). Başarısızlık nedenleri anketi sonuçları ve çözüm önerileri raporu, Tatvan Rehberlik Araştırma Merkezi Müdürlüğü.

Metin, M. (2014). Kuramdan uygulamaya eğitimde bilimsel araştırma yöntemleri. Ankara: Pegem.

Özdamar, K. (2013). Paket programlar ile istatistiksel veri analizi. Eskişehir: Nisan.

Selçuk, E. (1997). Ingilizce dersine tutum ile bu dersteki akademik başarı arasındaki ilişki. (Unpublished master thesis). Abant İzzet Baysal University, Bolu.

Semerci,N., \& Semerci,Ç.( 2004). Türkiye'de öğretmenlik tutumları. Fırat University Journal of Social Science, 14(1), 137-146.

Sezgin, M. (2013). Öğrencilerin matematiğe yönelik tutumlarının akademik özyeterlik algıları ve algıladıkları ögretmen davranışları açısından incelenmesi. (Unpublished master thesis). İstanbul Üniversitesi, İstanbul.

Şerif, M., \& Şerif, C. W. (1996). Sosyal psikolojiye giriş (M. Atakay \& A. Yılmaz, Trans.). İstanbul: Sosyal.

Taş, S. (2005). Illköğretim 6-7-8. sinıflarda matematik öğretiminde başarıya etki eden etmenler. (Unpublished master thesis). Yüzüncü Y1l Üniversitesi, Van.

Turgut, M. F. (1992). Eğitimde ölçme ve değerlendirme metotları. Ankara: Saydam.

Varış, F. (1998). Eğitim bilimlerine giriş. İstanbul: Alkım. 
Yılmazer, A., \& Demir, S. B. (2014). Ortaokul öğrencilerinin sosyal bilgiler dersine ve sosyal bilgiler öğretmenine karşı tutumları ile akademik başarıları arasındaki ilişskinin incelenmesi, Turkish Studies, 9(2), 1705-1718.

Zan, R., \& Di Martino, P. (2007). Attitude toward mathematics: Overcoming the positive/negative dichotomy. The Montana Mathematics Enthusiast, Monograph, 3(2007), 157-168.

\section{Turkish Abstract \\ Lise Öğrencilerinin Öğretmenlerine Yönelik Tutumlarının Belirlenmesi}

$\mathrm{Bu}$ araştırmada, lise öğrencilerinin öğretmenlerine yönelik tutumlarını, bazı değişkenlere, tutum ve başarıları arasındaki ilişkiye göre belirlemek amaçlanmıştır. Dolayısıyla çalışma, ilişki araştırması modeline göre tasarlanmıştır. Bu çalışmada öğrencilerin öğretmenlerine yönelik tutumlarını ortaya çıkarmak için "Öğrencilerin Öğretmene Yönelik Tutum Ölçeği (SOSATT)" veri toplama aracı olarak kullanılmıştır. Araştırma sonucunda öğrencilerin öğretmenlerine yönelik tutumlarının pozitif olduğu ve lise öğrencilerinin öğretmenlerine yönelik tutumlarının lise eğitiminde çok fazla değişmediği ve dokuzuncu sınıf öğrencilerinin öğretmenlerine yönelik tutumlarının cinsiyete göre önemli ölçüde değişmediği saptanmıştır.

Anahtar Kelimeler: öğretmen, tutum, başarı, öğrenci tutumu, lise öğrencileri, belirleme

\section{French Abstract \\ Détermination des Attitudes des Lycéens envers Leurs Professeurs}

Dans l'étude actuelle, le but est de déterminer les attitudes des lycéens envers leurs professeurs selon quelques variables et la relation entre leurs attitudes et accomplissements. Ainsi, l'étude a été conçue selon le modèle d'enquête relationnel. Dans l'étude actuelle, "l'Échelle des Attitudes des Étudiants envers le Professeur (SOSATT)" a été utilisée comme un instrument de collecte de données pour susciter les attitudes des étudiants envers leurs professeurs. Il a été trouvé que les attitudes des étudiants envers leurs professeurs sont positives et les attitudes des lycéens envers leurs professeurs ne varient pas beaucoup partout dans leur éducation de lycée et les attitudes des étudiants de troisième envers leurs professeurs ne varient pas significativement selon le genre en termes du score total pris de l'échelle.

Mots Clés: professeur, attitude, accomplissement, les attitudes d'étudiants, lycéens, détermination 


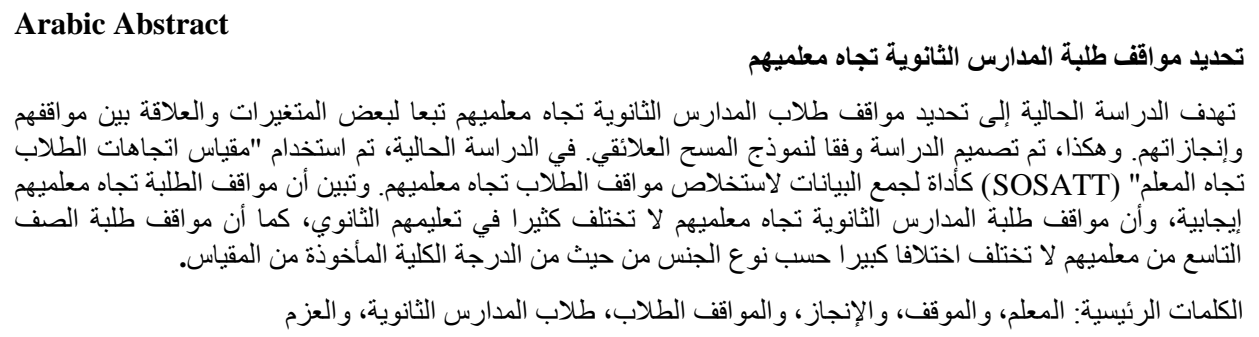

\section{German Abstract}

Ermittlung der Einstellungen der High School Students Gegenüber Ihren Lehrern

In der aktuellen Studie ist es das Ziel, die Haltung der Schülerinnen und Schüler gegenüber ihren Lehrern abhängig von einigen Variablen und dem Verhältnis zwischen ihren Einstellungen und Leistungen zu bestimmen. So wurde die Studie nach dem relationalen Vermessungsmodell entworfen. In der aktuellen Studie wurde " The scale of student Attitudes towards the Teacher (SOSATT)" als Datenerfassungsinstrument verwendet, um die Einstellung der Schüler gegenüber ihren Lehrern hervorzurufen. Es wurde festgestellt, dass die Einstellung der Schüler gegenüber ihren Lehrern positiv ist und die Haltung der Schülerinnen und Schüler in Bezug auf ihre LehrerInnen nicht viel in ihrer Hochschulausbildung variiert und die Einstellung der neunten Schülerinnen und Schüler zu ihren Lehrern nicht unterschiedlich von Geschlecht unterschiedlich ist der Gesamtpunktzahl aus der Skala.

Schlüsselwörter: lehrer, haltung, leistung, schüler-einstellungen, gymnasiasten, entschlossenheit

\section{Malaysian Abstract \\ Penentuan Sikap Pelajar Sekolah Menengah ke Arah Guru Mereka}

Dalam kajian semasa, matlamatnya adalah untuk menentukan sikap pelajar sekolah menengah ke arah guru mereka bergantung kepada beberapa pemboleh ubah dan hubungan antara sikap dan pencapaian mereka. Oleh itu, kajian ini direka bentuk mengikut model kaji selidik hubungan. Dalam kajian semasa, "Sikap Skala Pelajar terhadap Guru (SOSATT)" digunakan sebagai alat pengumpulan data untuk menimbulkan sikap pelajar terhadap guru mereka. Didapati bahawa sikap pelajar terhadap guru mereka adalah positif dan sikap pelajar sekolah menengah ke arah guru mereka tidak banyak berubah sepanjang pendidikan sekolah menengah dan sikap pelajar kelas kesembilan terhadap guru mereka tidak bervariasi dengan ketara oleh jantina daripada jumlah skor yang diambil daripada skala.

Kata Kunci: guru, sikap, pencapaian, sikap pelajar, pelajar sekolah menengah, tekad 


\section{Russian Abstract \\ Определение Отношения Учащихся Средней Школы к Учителям}

Целью данного исследования является определение отношение старшеклассников к своим учителям в зависимости от некоторых переменных и между их достижениями. Таким образом, исследование было разработано в соответствии с моделью реляционных исследований. В текущем исследовании «Масштабы Отношения Учеников к Учителю (SOSATT)» использовалась в качестве инструмента сбора данных, чтобы выявить отношение учеников к своим учителям. Было обнаружено, что отношение учеников к своим учителям положительное, а отношение старшеклассников к их учителям не сильно отличаются в течение всего школьного образования и отношение учеников девятого класса к их учителям существенно не меняется по признаку пола с точки зрения общей оценки, взятой из шкалы.

Ключевые Слова: учитель, отношение, достижения, отношение учащихся, ученики старших классов, определение 